\title{
UAV application for site suitability mangrove replantation program, case study in Pasuruan and Probolinggo, East Java
}

\author{
Arief Darmawan ${ }^{1,2 *}$, Dhira K. Saputra ${ }^{1,2}$, M Arif Asadi ${ }^{1,2}$, and I Wayan Gede Astawa \\ Karang $^{3}$ \\ ${ }^{1}$ Faculty of Fisheries and Marine Science, Universitas Brawijaya, Malang, Indonesia \\ ${ }^{2}$ Corect RG, Faculty of Fisheries and Marine Science, Universitas Brawijaya, Malang, Indonesia \\ ${ }^{3}$ Faculty of Marine Science and Fisheries, Udayana University, Bali, Indonesia
}

\begin{abstract}
In the northern coast of East Java, mangrove naturally growth along the coastline of most regencies, and becomes the important factor in the sustainability of fisheries, protection and other environmental services for communities in coastal areas. The last few decades, satellite remote sensing becomes the most widely used tool for mangrove monitoring purpose. Various types of sensory satellite images are used for mapping areas, types and densities, estimating the mangrove biomass. Meanwhile, UAV (Unmaned Aerial Vehicle) is rapidly developed and quite affordable. Various footages and photogrammetry works carried out with the lightweight UAV. Therefore, utilizing UAVs for capturing mangrove areas can be an effective solution to identify area where rehabilitation should be conducted. The research aimed to use the consumer grade DJI Phantom 4 Pro for mapping 92,6 Ha mangrove area in Rejoso (Pasuruan) and 69,37 Ha of Sumberasih (Probolinggo). Result of this study shows the capability of UAV to provide detail mangrove image (canopy density, characteristics and environmental profile), which can be used to support the management activities, particularly mangrove replantation program. Also, it could be a low cost solution and time effective of mangrove monitoring, compared with previous approach of high-resolution satellite imagery.
\end{abstract}

\section{Introduction}

Mangroves in practical definition are typical plants that grow on the seashore or the river estuary, influenced by tides and able to adapt with saline water of tropical and sub-tropical regions. Mangroves cannot grow on the steep coast with strong waves and high tides because this does not support the deposition of muds and sands as substrate that required for their growth [1]. Furthermore, mangroves habitats are muddy soils, peat soil and open to waves, salinity and tidal influences [2,3]. Moreover, there were 7 key of environment factors that require for mangrove growth, those consisted of (1) air temperature, (2) protected coastline, (3) currents, (4) substrate type, (5) shallow shores, (6) salt water and (7) tidal range [2]. As consequence, mangrove shows number of specific morphological and

Corresponding author: ariefdarma@ub.ac.id 
physiological adaptation that makes them able to colonize and dominate in the dynamic and harsh environment [4].

Indonesia as a tropical country have a large mangrove area that spread from Sumatra Papua Island. [5], [6]. About 3 million hectares of mangrove forest grow along 95,000 kilometers of coastal Indonesia. This number represents $23 \%$ of the world's total mangrove ecosystem [7]. Meanwhile, the distribution of the area and mangrove forests in East Java Province is dominant on the northern coast such as in Lamongan, Gresik, Surabaya, Sidoarjo, Pasuruan, and Probolinggo Regencies. Meanwhile, the mangrove area in the east lies in the districts of Jember, Banyuwangi and Situbondo, which in the colonial period were the areas of the Besuki Residency, then a small portion is on the south coasts such as in Clungup (Malang), Sine and Brumbun Beach (Tulungagung) and Pancer Cengkrong Beach (Trenggalek). Therefore, regarding its spreading area and extents, mangrove forest considered into one of the important habitats to be managed in East Java Province.

The last few decades, the most popular mapping of mangrove areas is to use the remote sensing method. Various types of sensory satellite images are used for mapping areas, types and densities, estimating the mangrove biomass. But, although using high resolution sensor, there are constraints to get data of mangrove area with satellite images such as clouds cover, cost and also time to obtain it. At the other hands, UAV technology is rising and it make process to obtain image of mangrove area easier and faster. Due low altitude of flight, UAV is possible produce images with no cloud cover and it can be conducted at the time where needed. As continue, the objectives of this research are to test ability of aerial photograph that taken from UAV as data source for identify mangrove area and to define area for next mangrove replanting.

\section{Methods}

This research were carried out int two principal mangrove region in north coast of East Java, includes Rejoso Sub-district, Pasuruan and Sumberasih Sub-district in Probolinggo as shown by Figure 1 .

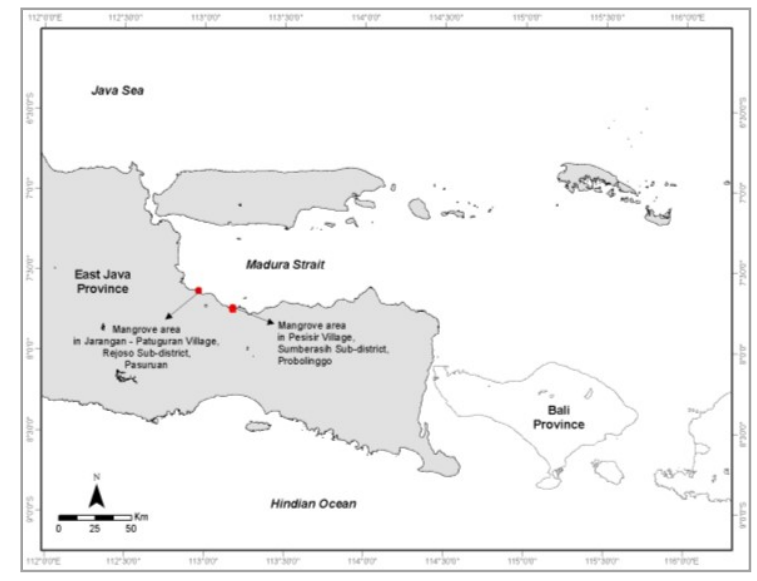

Fig. 1. Map of research locations

A Dji Phantom 4 Pro aircraft were set up on $75 \mathrm{~m}$ of flight altitude, with $80 \%$ of both front and side image overlay. This produce a $2,06 \mathrm{~cm} / \mathrm{px}$ value of GSD. Aerial photo taken by UAV DJI Phantom 4 where the flight settings arranged with DroneDeploy ${ }^{\circledR}$. Furthermore, Aerial photographs that taken from those two research areas were processed to create orthophoto. This orthophoto were further analysed using supervised classification 
tools in ArcGIS 10.5 to classify the vegetation density and land characteristics.. The ground survey carried out in 5 stations, aimed to collect vegetation data include species, tree height, diameter, as well as record the substrate and environmental suitability for mangrove replantation program. Interview with local stakeholders completed the informations related to the forest evolution and rehabilitation program in the survey area. According that results, suggestion about areas for the next replanting were defined as well as calculated area.

\section{Results and Discussions}

\subsection{Results}

\section{Mangrove in Rejoso and Sumberasih}

Mangrove in Rejoso represents both riverine and front mangrove stands. This mangrove area consists of two different villages, Jarangan and Patuguran village. The boundary of its mangrove area was defined by Rejoso River. UAV flight mission were started at the morning, and it takes 2 hours to completed the 92,6 Ha area of mangrove (Figure 2).

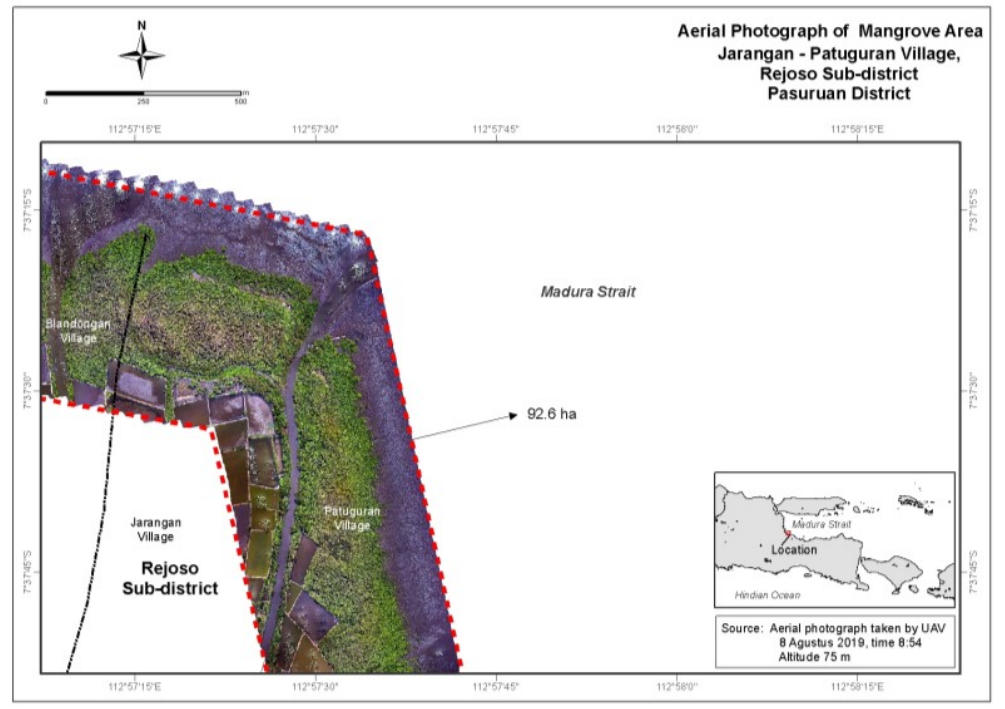

Fig. 2a. Aerial photograph of mangrove area in Rejoso Sub-district, Pasuruan

Mangrove in Rejoso dominated by natural stands Avicennia spp in the front mangrove, where Sonneratia caseolaris covered the riverine and back mangrove in west side of Rejoso River. Some pathcy-replanted Rhizopora spp found in front of coastline. Dense mangrove stands with vegetation height varies from 5 to $12 \mathrm{~m}$. There are abundant stocks of Avicennia spp. seedlings $\left(>5 \mathrm{ind} / \mathrm{m}^{2}\right)$, indicates its good natural regeneration. Sonneratia caseolaris found in the riverine mangrove formation of Jarangan village (western part of the Rejoso rivermouth). This area also considered as important Sonneratia natural seeds bank, as seedlings can be found almost every inch of its forest floor. 

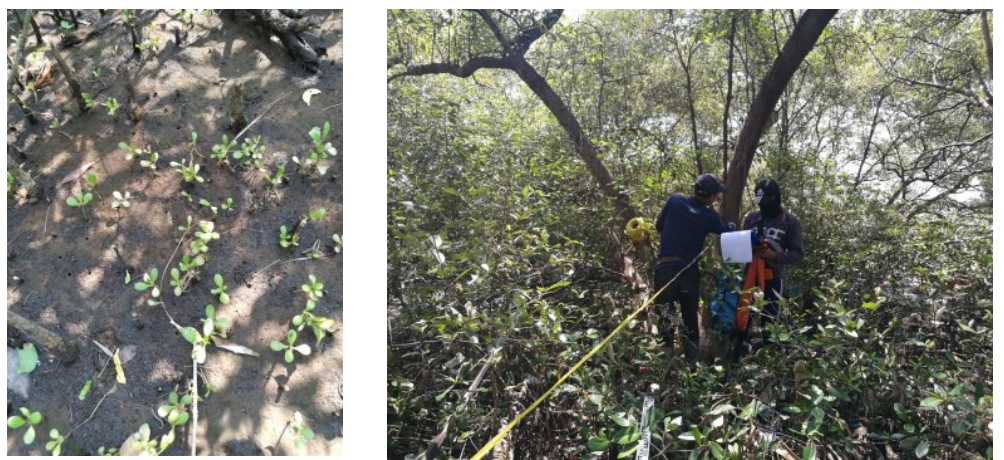

Fig. 2b. Abundant natural seedlings of $S$. caseolaris (left) and A. marina (right) found in the forest floor of Rejoso mangrove area.

Mangrove in Sumberasih Sub-district, Probolinggo, consist of eastern part $(69,37 \mathrm{Ha})$ and western part $(76,15 \mathrm{Ha})$ of Sumberasih rivermouth, as shown in Figure 3. Eastern part of Sumberasih mangrove considered as natural stands of Avicennia spp., while western part consist of combined natural stands of Avicennia spp. and replanted Rhizopora spp. Due to the strong winds opposite the flight path, it takes 6 hours and consume 20 batteries to finish all the flight missions.

The environmental profile in this area belongs to gently-sloped tidal flat. There is a tidal channel which consist of saline soil (evaporite sediment) in the east side Sumberasih's mangrove (Figure 8). Mangrove cannot grown in this barren section, caused by it's soil salinity and compactness. Compared with substrate composition in Rejoso, the soil in Sumberasih mangrove area consists of sand-dominated substrate (back mangrove), while the mangrove forest floor dominated by fine particles (mud). In the front mangrove (adjacent to the coastline), subtrate characterized by thin layer of mud with abundance of barnacles.
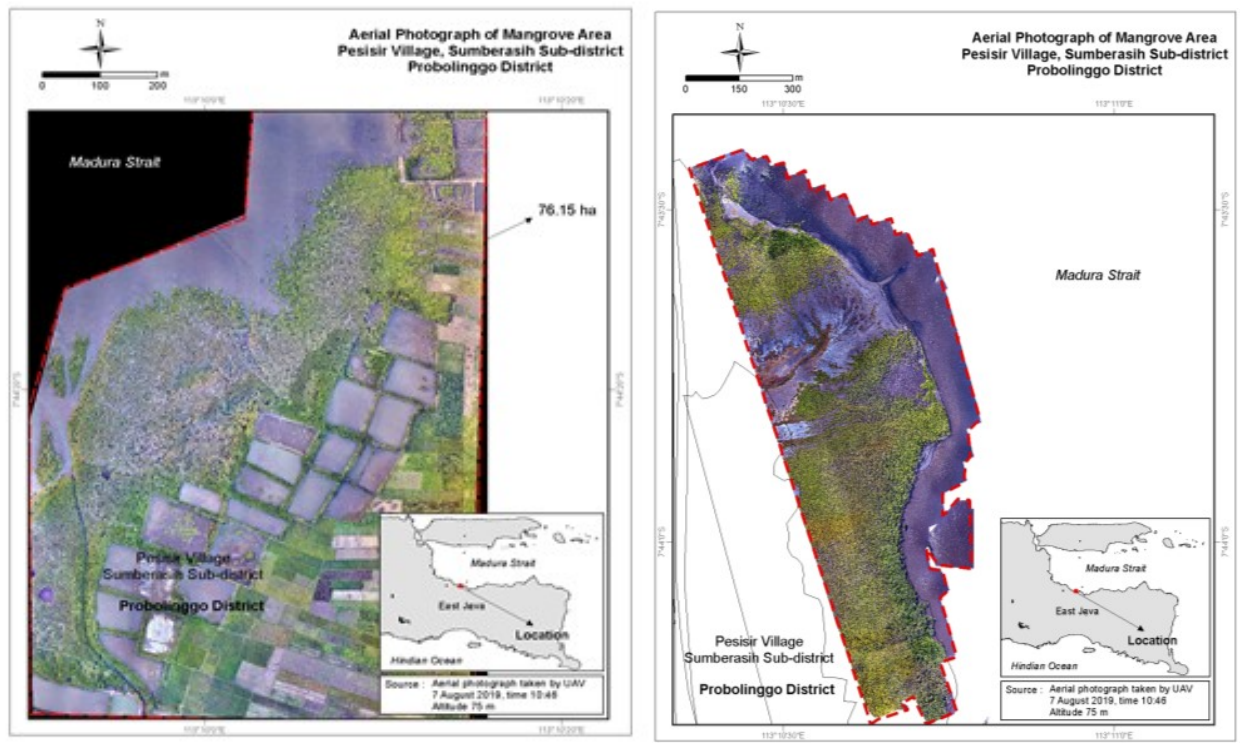

Fig. 3. Aerial photograph of mangrove area in western part of Sumberasih River (left), and mangrove area in the eastern part of Sumberasih river (right) 


\section{Image anlysis and interpretation}

The orthophoto resulted from UAV processing in both areas continued to analysed using ArcGIS 10.5 classification tool. Result of supervised classifications shown in Figure $4 \mathrm{a}$ and Figure $4 \mathrm{~b}$.
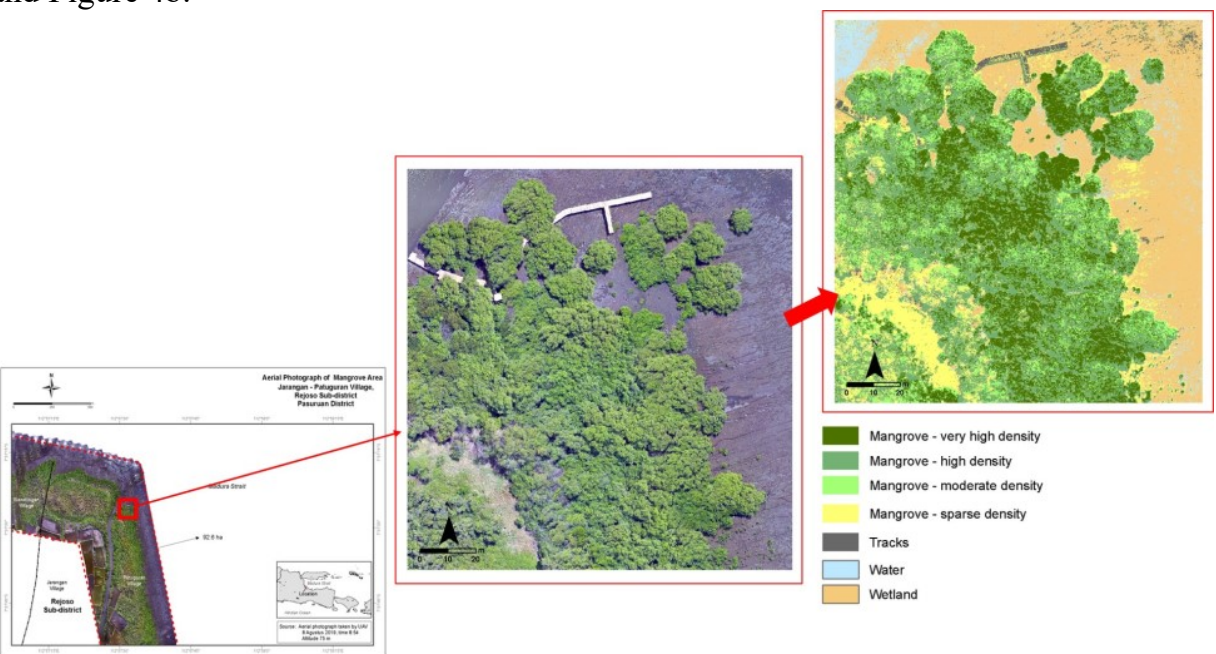

Fig. 4a. Classification of aerial photograph in Rejoso Sub-district, Pasuruan

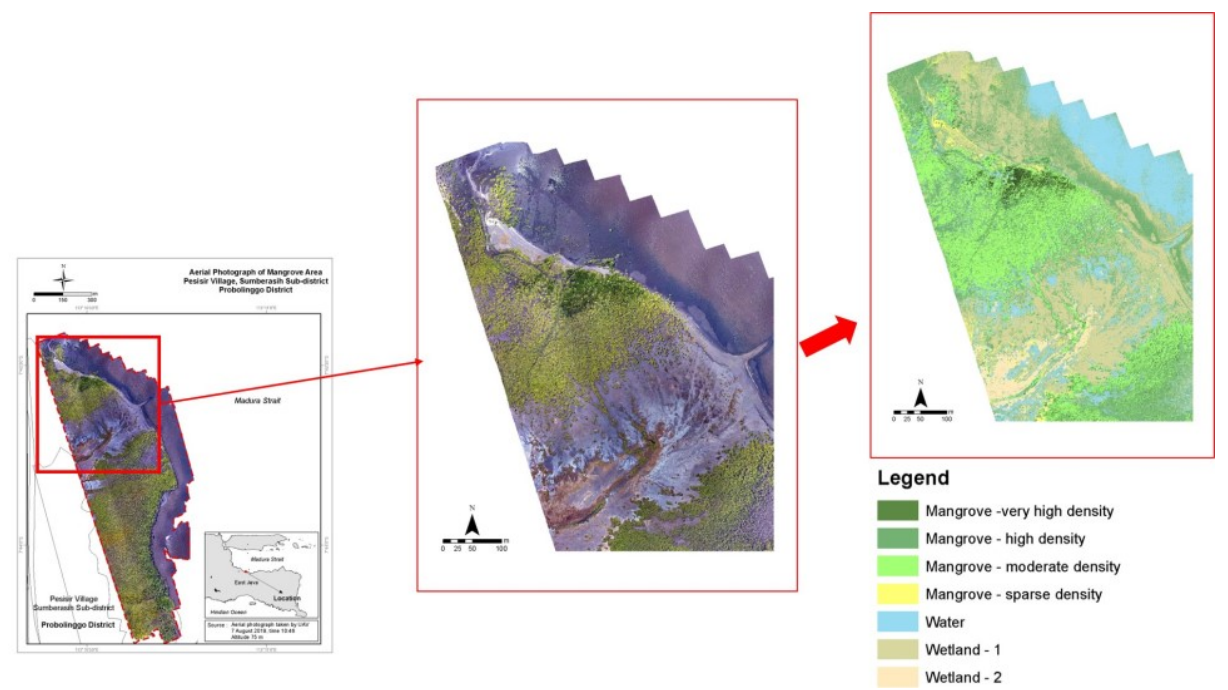

Fig. 4b. Classification of aerial photograph in Sumberasih Sub-district, Probolinggo

Area that was suggested for the next replantation in Rejoso Sub-district consist of 0,51 $\mathrm{Ha}$ as shown by Figure 5. Both areas located in two different sides. First location was proposed in front of mangrove area $(0,45 \mathrm{Ha})$ where second location proposed in the back mangrove area $(0,06 \mathrm{Ha})$. This second location identified as abandoned area after past logging activity. 

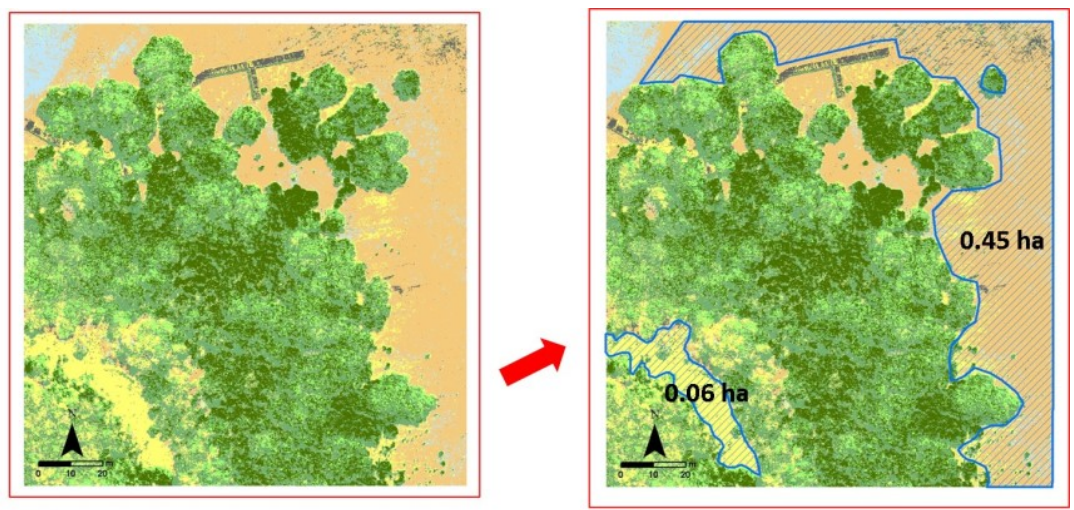

Mangrove - very high density

Mangrove - high density

Mangrove - moderate density

Mangrove - sparse density

Tracks

Water

Wetland

Fig. 5. Areas recommend for future mangrove replantation activities in Jarangan and Patuguran village, Rejoso Sub-district, Pasurua

In Sumberasih, the western part of the river consists of vast mudflat area, which is suitable for mangrove growth, and resulted into constant seaward development of 23,19 Ha mangrove in this area. However, there are still some spots which is suitable for planting activities (especially surrounding the abandoned farms). The purpose of planting in the area is to replace damaged vegetation (Figure 6).
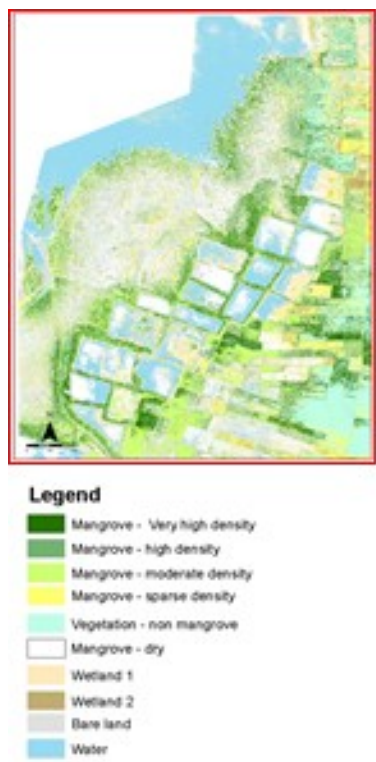

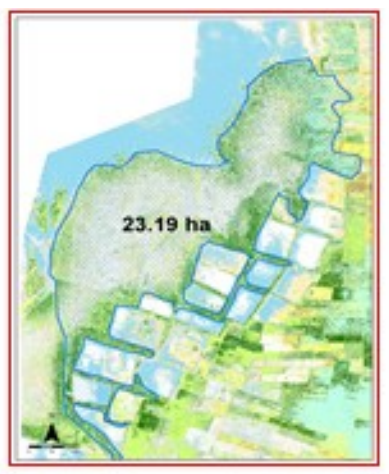

20 Recommendation for the next replantation

Fig. 6. Mangrove stands in western part of Sumberasih rivermouth. Some areas still available for mangrove replanting activities, aprticularly abandoned farms. 


\subsection{Discussions}

Both study areas represent front mangrove dominated by Avicennia spp, as the natural mangrove stands in most part of northern coast of East Java. However, some rehabilitation activities have carried out since early 2000's to restore damaged coastal forest in the areas.

This research shows the capability of consumer grade UAV Dji Phantom 4 Pro to provide detailed mangrove image as well as environmental condition in Pasuruan and Probolinggo. Using selected flight setting (AOC $70^{\circ}$, front overlap: $80 \%$, side overlap: $80 \%$ ) at $75 \mathrm{~m}$ altitude, provide high resolution image with the GSD value of 2,06 cm/px. This result can display quite well in terms of mangrove canopy characteristics and also the environmental properties, for example, rare saline soil features located in the tidal channel of mangrove Sumberasih (Figure 7).

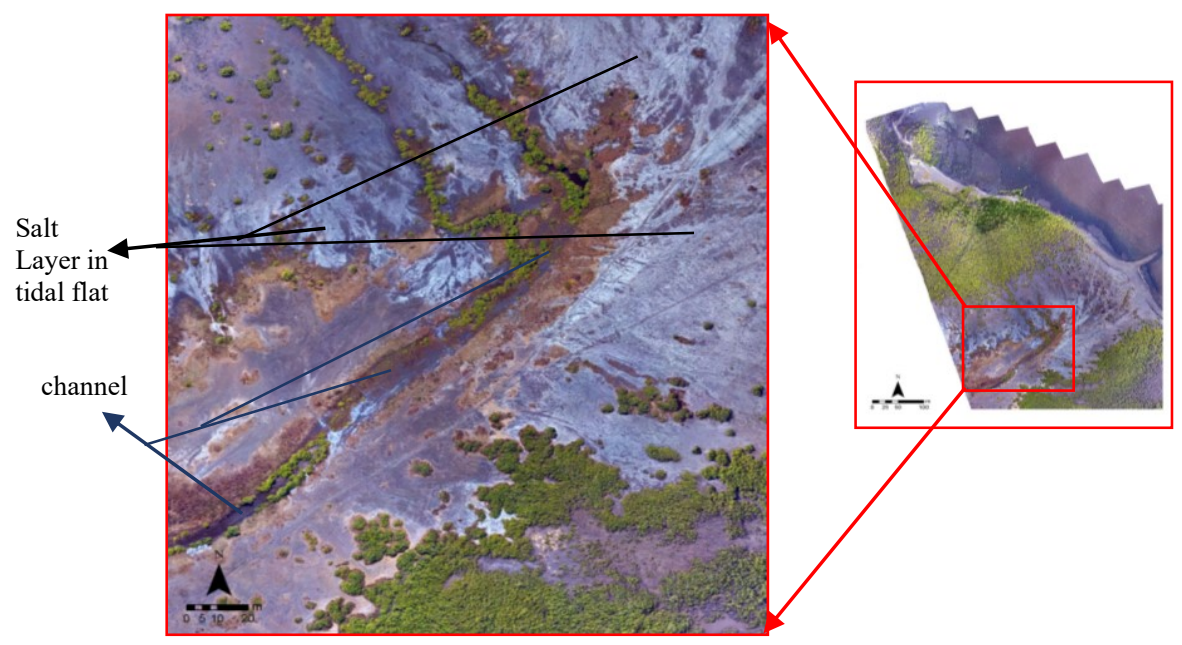

Fig. 7. Image shows tidal channel with thin salt layer on the sediment of mangrove area Pesisir Village, Sumberasih

The feature as seen in Figure 7 rarely found in other mangrove areas in the northen coast of Java. Naturally Avicennia spp. seedlings are not found in this area, because the tidal currents carries a loose topsoil layer seaward during ebb tide, and leaves a compact substrate with a layer of evaporite feature on it. Approximately, this arid area is covers up 10,13 Ha, as delineated in Figure 4b. This barren area surround by dense Avicennia spp. cover with tree height range from 3-10 $\mathrm{m}$ and high number of seedlings. According to the substrate condition, this open area is not recommend for mangrove planting activities [8].

Images obtained from UAV missions show the specific color pattern among mangrove families. Figure 2a shows different color pattern of Avicenniaceae (eastern side of Rejoso rivermouth), Rhizoporaceae (western part, front mangrove) and Sonneratiaceae (western part, riverine and back mangrove). This will make it easier to calculate the extent of mangrove cover based on family or genus. By understanding species of existing natural mangroves, it can be a good recommendation for the species selection for mangrove replantation program, as the importance to select the species based on the existing mangrove stands in the replanted site $[8,9]$. 


\section{Conclusions}

Aerial photographs taken from UAV can be used as a tool for mangrove replanted area mapping and for planning the next replanting area. Furthermore, flight planning including altitude, flight path and flight time were important factors to produce image characteristic and its quality as well. Overall process to obtain aerial photographs using UAV relatively faster and need lower cost compared to high resolution satellite imagery.

Authors would like to appreciate BRCS of Universitas Brawijaya for research funding (HPP, DIPA UB: No. DIPA-696. 49/UN10.C10/PN/2019) and supporting team: Khabib Taufik Putra, Ahmar Ananto Pratama, Prasetyo Nugroho, and Afif Olivian D.

\section{References}

1. A. Nontji, Laut Nusantara (Ikrar Mandiriabadi, Jakarta, 2005)

2. V. Chapman, Wet Coastal Ecosystems of the World I (Elsevier Scientific Publishing Company, Amsterdam, 1977)

3. J. Bunt, W. Williams, Vegetational Relationships in the Mangroves of Tropical Australia (Marine Ecology Progress Series ,2007)

4. R. Carter, Coastal Environtments : An Introduction to the Physical, Ecological and Cultural Systems of Coastlines (Academic Press, London, 1988)

5. W. Atmadja, Soeroyo. Proceedings of Regional Symposium on Living Resources in Coastal Areas, 441-451 (ASEAN Australian Cooperative Program in Marine Sciences, Australian Institute of Marine Science and University of the Philippines, 1991)

6. Food and Agriculture Organization (FAO), The world's mangroves 1980-2005 (2007)

7. C.Giri, E. Ochieng, L. Tieszen, Z. Zhu, A. Singh, T.Loveland, J. Masek, N. Duke, Global Ecology and Biogeography 20(1), 154-159 (2011)

8. R. Lewis, III. Ecol. Eng. 24(4), 403-418 (2005)

9. MAP-Indonesia. 5 Steps to Successful Ecological Restoration of Mangroves. (Mangrove Action Project-Indonesia, 2006) 